\title{
Crude extract of Euphorbia formosana inhibits the migration and invasion of DU145 human prostate cancer cells: The role of matrix metalloproteinase-2/9 inhibition via the MAPK signaling pathway
}

\author{
JIUN-LONG YANG ${ }^{1}$, JU-HWA LIN ${ }^{2}$, SHU-WEN WENG $^{3,4}$, JAW-CHYUN CHEN $^{5}$, JAI-SING YANG ${ }^{6}$, \\ SAKAE AMAGAYA $^{7}$, SHINJI FUNAYANA ${ }^{8}$, W. GIBSON WOOD ${ }^{9}$, CHAO-LIN KUO $^{1}$ and JING-GUNG CHUNG ${ }^{2,10}$ \\ Departments of ${ }^{1}$ Chinese Pharmaceutical Sciences and Chinese Medicine Resources and ${ }^{2}$ Biological Science \\ and Technology; ${ }^{3}$ Graduate Institute of Chinese Medicine, China Medical University, Taichung $404 ;{ }^{4}$ Department of \\ Chinese Medicine, Taichung Hospital, Department of Health, Executive Yuan, Taichung 403; ${ }^{5}$ Department of Medicinal \\ Botany and Healthcare, Da-Yeh University, Changhua 515; ${ }^{6}$ Department of Pharmacology, China Medical University, \\ Taichung 404, Taiwan, R.O.C.; Departments of ${ }^{7}$ Kampo Pharmaceutical Sciences and ${ }^{8}$ Medicinal Chemistry, \\ Nihon Pharmaceutical University, Saitama, Japan; ${ }^{9}$ Department of Pharmacology, University of Minnesota, \\ School of Medicine, Geriatric Research, Education and Clinical Center, VA Medical Center, Minneapolis, \\ MN 55455, USA; ${ }^{10}$ Department of Biotechnology, Asia University, Taichung 413, Taiwan, R.O.C.
}

Received December 21, 2012; Accepted February 26, 2013

DOI: $10.3892 / \mathrm{mmr} .2013 .1380$

\begin{abstract}
Prostate cancer is a common worldwide health problem in males with a poor prognosis due in part to tumor invasion and migration. The crude extract of Euphorbia formosana (CEEF) has been used for the treatment of numerous diseases, however, its effects on the migration and invasion of prostate cancer cells have yet to be examined. In the present study, we investigated the effects of CEEF on the migration and invasion of DU145 human prostate cancer cells in vitro. The wound healing assay and the Matrigel-uncoated migration assay were used to examine the migration of cancer cells. Western blotting was used to examine the levels of proteins associated with migration and invasion, and gelatin zymography was used to examine the secretion levels of matrix metalloproteinases-2 and -9 (MMP-2/9) from DU145
\end{abstract}

Correspondence to: Professor Jing-Gung Chung, Department of Biological Science and Technology, China Medical University, No 91, Hsueh-Shih Road, Taichung 404, Taiwan, R.O.C.

E-mail: jgchung@mail.cmu.edu.tw

Dr Chao-Lin Kuo, Department of Chinese Pharmaceutical Sciences and Chinese Medicine Resources, China Medical University, No 91, Hsueh-Shih Road, Taichung 404, Taiwan, R.O.C.

E-mail:clkuo@mail.cmu.edu.tw

Key words: crude extract of Euphorbia formosana, DU145 human prostate cancer cells, migration, MMP-2, MMP-9, MAPK signaling pathway cells following exposure to CEEF. The results indicated that CEEF suppressed the migration and invasion of DU145 prostate cancer cells and that these effects are exerted in a concentration- and time-dependent manner. CEEF inhibited the ERK1/2, p38, JNK, SOS1, PKC, PI3K and MMP-2/9 protein expression in DU145 cells. The results demonstrated that CEEF suppressed the migration and invasion of DU145 cells through inhibition of the mitogen-activated protein kinase (MAPK) signaling pathway resulting in the inhibition of MMP-2/9 in DU145 human prostate cancer cells.

\section{Introduction}

Prostate cancer is the second leading cause of cancer-related mortality in males worldwide (1-3). In the Western world, prostate cancer is the second leading cause of cancer-related mortality in males due to its high prevalence and metastatic rate (4-5). In Taiwan, prostate cancer is the seventh leading cause of cancer-related mortality (6). Prostate cancer has a poor prognosis due in part to tumor invasion and migration. The propensity of prostate cancer cells to metastasize to the bone greatly reduces the effectiveness of available treatment options (7-9).

It is well documented that cancer patients succumb to the disease primarily as a result of metastasis of the cancer to distant organs $(10,11)$. Metastasis is a multistep process, including cancer cell adhesion, migration, intravasation, extravasation and colonization to a secondary site (12-15). Thus, disruption of the metastatic process is key to reducing cancer mortality in patients. Mitogen-activated protein kinase (MAPK) signaling contributes to human cancer cell migration, invasion and metastasis (16-18). The molecular mechanics of cancer cell migration 
has been reported to involve cell cytoskeletal remodeling and focal adhesion dynamics $(19,20)$. Matrix metalloproteinases (MMPs) are important in cell growth, angiogenesis, invasion and metastasis of cancer cells (16,21-23). Therapeutic agents that are capable of inhibiting MMPs may be efficacious. However, studies of MMP inhibitors, including batimastat (BB-94) for rat mammary carcinoma $(24,25)$ and FYK-1388 for human fibrosarcoma have thus far been disappointing due to serious adverse effects (26). Therefore, much attention has been focused on developing new MMP inhibitors.

Crude extract of Euphorbia formosana (CEEF) has been used for the treatment of several diseases in the Chinese population (27). However, the effects of CEEF on the migration and invasion of prostate cancer cells has not been examined. In the present study, we investigated the effects of CEEF on the inhibition of cell migration and invasion in DU145 human prostate cancer cells. We demonstrated that CEEF inhibited cell migration and invasion in DU145 cells by suppressing the MAPK signaling pathway resulting in the inhibition of MMP-2/9.

\section{Materials and methods}

Cell culture and reagents. The DU145 human prostate cancer cell line was purchased from the Food Industry Research and Development Institute (Hsinchu, Taiwan). Minimum Essential Medium (MEM), fetal bovine serum (FBS), L-glutamine, penicillin-streptomycin and trypsin-EDTA were obtained from Gibco BRL (Carlsbad, CA, USA). Dimethyl sulfoxide (DMSO), propidium iodide (PI), trypan blue and Tris- $\mathrm{HCl}$ were purchased from Sigma (St. Louis, MO, USA). The crude extract of Euphorbia formosana was kindly provided by Dr Kuo (Department of Chinese Pharmaceutical Sciences and Chinese Medicine Resources, China Medical University, Taichung, Taiwan) (16).

Cell viability. DU145 cells $\left(2 \times 10^{5}\right.$ cells/well $)$ were seeded in a 12 -well plate at $37^{\circ} \mathrm{C}$ with $5 \% \mathrm{CO}_{2}$ in MEM (Gibco BRL), supplemented with $10 \% \mathrm{FBS}, 100 \mathrm{mg} / \mathrm{ml}$ streptomycin and $100 \mathrm{U} / \mathrm{ml}$ penicillin for $24 \mathrm{~h}$. The cells were incubated with $100 \mu \mathrm{g} / \mathrm{ml} \mathrm{CEEF}$ or vehicle control (0.5\% DMSO) for 0, 6, 12, 24, 48 and $72 \mathrm{~h}$. The cells were then detached with trypsin, harvested, washed with PBS and stained with trypan blue. The cell number for each treatment was manually counted using a hemocytometer and presented as a percentage of viable cells per ml (28).

Wound healing assay. DU145 cells at a density of $1 \times 10^{6}$ cells/ well were cultured in $10 \mathrm{~cm}$ petri dishes until cells reached 90-95\% confluency. The surface of the plate was then scratched with a pipette tip and washed three times. Cells were incubated in the absence and presence of CEEF for 0, 6, 12 and $24 \mathrm{~h}$ and then imaged using a Nikon Eclipse TS100 microscope (29).

Cell migration and invasion assays. The migration of DU145 cells was determined using Matrigel-uncoated transwell cell culture chambers ( $8 \mu \mathrm{m}$ pore size) as described previously (30). DU145 cells were incubated with $0,25,50$ and $75 \mu \mathrm{g} / \mathrm{ml}$ of CEEF for 24 and $48 \mathrm{~h}$. The upper surface of the membrane containing the non-invaded cells were removed and the invaded cells on the lower surface of the membrane were fixed and stained with hematoxylin and eosin (H\&E). Migrating cells in the chamber were counted. For the determination of cell invasion, the same migration assay was used although the membrane was coated with Matrigel (29).

Western blotting assay for the detection of migration and invasion associated proteins in DU145 cells. DU145 cells at a density of $5 \times 10^{6}$ cells were maintained in a 6 -well plate overnight and then treated with $100 \mu \mathrm{g} / \mathrm{ml} \mathrm{CEEF} \mathrm{for} 0,6,12,24$, 48 and $72 \mathrm{~h}$. Cells were harvested and lysed with lysis buffer containing $40 \mathrm{mM}$ Tris- $\mathrm{HCl}$ (pH 7.4), $10 \mathrm{mM}$ EDTA, $120 \mathrm{mM}$ $\mathrm{NaCl}, 1 \mathrm{mM}$ dithiothreitol and $0.1 \%$ Nonide P-40. The protein concentration of the lysate was determined using the Bio Red kit. Proteins from each sample were separated using sodium dodecyl sulfate-PAGE and transferred to nitrocellulose membranes (Amersham Pharmacia Biotech, Piscataway, NJ, USA) by electroblotting. The membranes were probed with primary antibodies for $24 \mathrm{~h}$ and then washed and stained with secondary antibody for enhanced chemiluminescence (NEN Life Science Products, Inc., Boston, MA, USA) as previously described (29).

Real-time PCR of mRNA expression levels of MMP-2/9 in DU145 cells. Cells $\left(1 \times 10^{6}\right.$ cells/well) were placed in 6-well plates and incubated with CEEF $(50 \mu \mathrm{g} / \mathrm{ml})$ for $24 \mathrm{~h}$. The cells were then collected and total RNA was extracted, as previously described(31).CollectedRNA sampleswerereversetranscribed using the High Capacity cDNA Reverse Transcription kit at $42^{\circ} \mathrm{C}$ for $30 \mathrm{~min}$ according to the manufacturer's instructions (Applied Biosystems, Foster City, CA, USA). The primers used were: MMP-2 forward: CCCCAGACAGGTGATCTTGAC and reverse: GCTTGCGAGGGAAGAAGTTG; MMP-9 forward: CGCTGGGCTTAGATCATTCC and reverse: AGGTTGGATACATCACTGCATTAGG; GAPDH forward: ACACCCACTCCTCCACCTTT and reverse: TAGCCAAATTCGTTGTCATACC. An Applied Biosystems 7300 Real-Time PCR system was used for each assay in triplicate and expression fold changes were derived using the comparative CT (threshold cycle) method (31).

Statistical analysis. Experiments were repeated at least three times. Results are shown as the mean \pm SD. The Student's t-test was performed to determine the statistical difference between the control- and CEEF-treated groups. $\mathrm{P}<0.05$ was considered to indicate a statistically significant result.

\section{Results}

CEEF affects the percentage of viable DU145 cells. DU145 cells were treated with $100 \mu \mathrm{g} / \mathrm{ml}$ of CEEF for $0,6,12,24,48$ and $72 \mathrm{~h}$, and the percentage of viable cells was determined by trypan blue exclusion assay. The results are shown in Fig. 1. Fewer viable cells were present with increasing time in CEEF-treated cells when compared with controls.

CEEF inhibits migration of DU145 cells. Monolayers of DU145 cells were scratched and treated with 50 and $75 \mu \mathrm{g} /$ $\mathrm{ml}$ of CEEF for $0,6,12$ and $24 \mathrm{~h}$, and allowed to recover to determine the rate of migration using the wound healing assay (Fig. 2). CEEF suppressed the migration of DU145 cells. The 


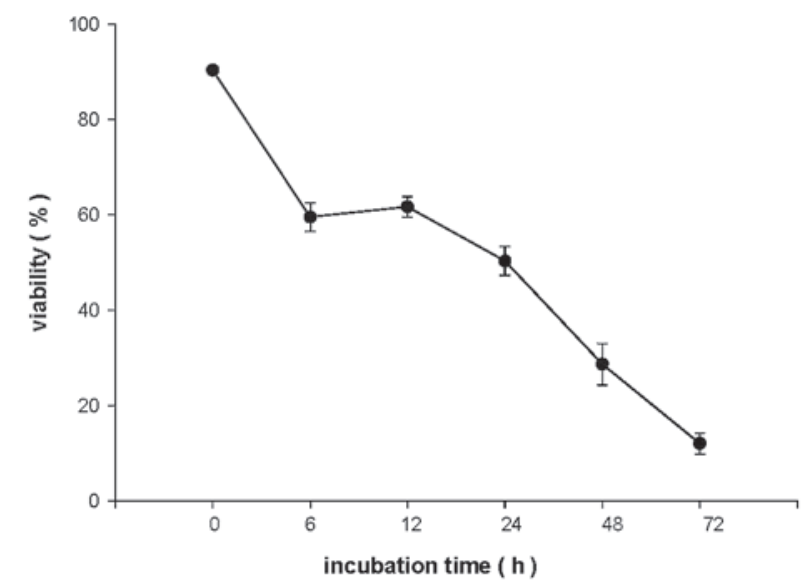

Figure 1. CEEF affects the percentage of viable DU145 cells. Cells in a 12-well plate were treated with 0 and $100 \mu \mathrm{g} / \mathrm{ml}$ of CEEF for $0,6,12,24,48$ and $72 \mathrm{~h}$. Cells were harvested and the percentage of viability was measured using the trypan inclusion assay as described in Materials and methods. CEEF, crude extract of Euphorbia formosana.

time required for wound closure of DU145 cells treated with CEEF for $24 \mathrm{~h}$ was significantly longer than that for the control cells.

CEEF inhibits the migration and invasion of DU145 cells. The effects of CEEF on the migration and invasion of DU145 cells are shown in Fig. 3. CEEF at concentrations between 25, 50 and $75 \mu \mathrm{g} / \mathrm{ml}$ significantly suppressed the migration of DU145 cells. The percentage of migration inhibition was $40-84 \%$ and $60-92 \%$ for cells incubated with CEEF for 24 and $48 \mathrm{~h}$, respectively, when compared with the control cells. CEEF inhibited the invasion of DU145 cells (Fig. 3B). Percent inhibition at CEEF concentrations of 25,50 and $75 \mu \mathrm{g} / \mathrm{ml}$ were $60-90 \%$ and $66-94 \%$ for 24 and $48 \mathrm{~h}$, respectively, when compared with the controls.

CEEF alters the levels of proteins associated with migration and invasion in DU145 cells. Data shown in Fig. 4A demonstrate that CEEF decreased the levels of ERK1/2, p38, JNK, SOS1, PKC and PI3K protein expression. Protein levels of MMP-2/9 were also reduced by CEEF treatment in DU145 cells (Fig. 4B). Based on these results, CEEF inhibits the ERK and PI3K/AKT signaling pathways which leads to the suppression of MMP-2/9 expression in DU145 cells.

CEEF alters $M R N A$ expression levels of MMP-2/9 in DU145 cells. Cells incubated with $100 \mu \mathrm{g} / \mathrm{ml}$ CEEF for $24 \mathrm{~h}$ and mRNA expression levels of MMP-2/9 were determined using real-time PCR. Fig. 5 demonstrates that CEEF significantly inhibits gene expression levels of MMP-2/9.

\section{Discussion}

Metastasis is one of the major causes of cancer-related mortality (31-35). At present, there is an intense effort to identify potential therapeutic agents that inhibit metastasis (35-38). We previously demonstrated that CEEF treatment significantly inhibits cell proliferation and induces cell cycle arrest control

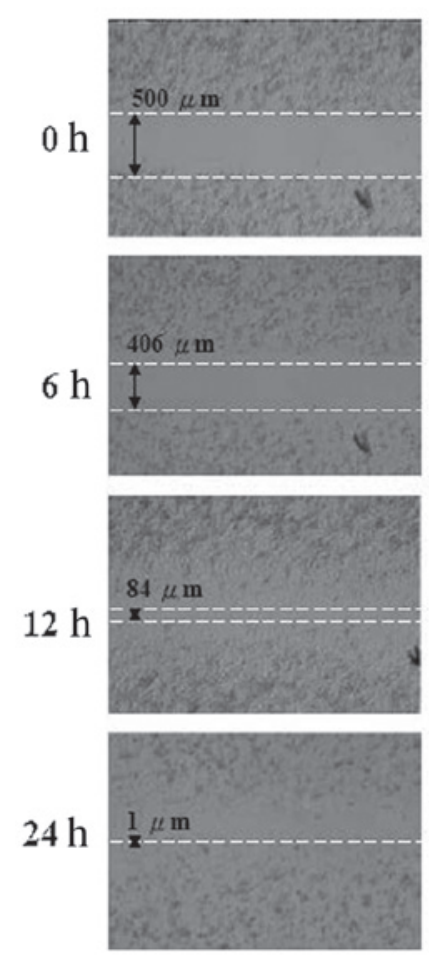

$50 \mu \mathrm{g} / \mathrm{ml}$
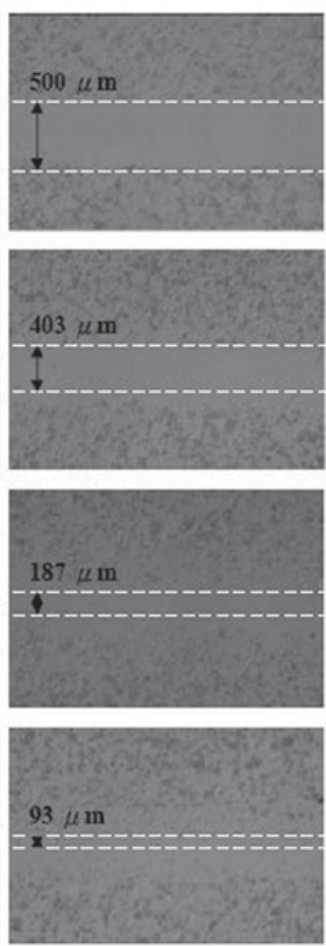

$75 \mu \mathrm{g} / \mathrm{ml}$
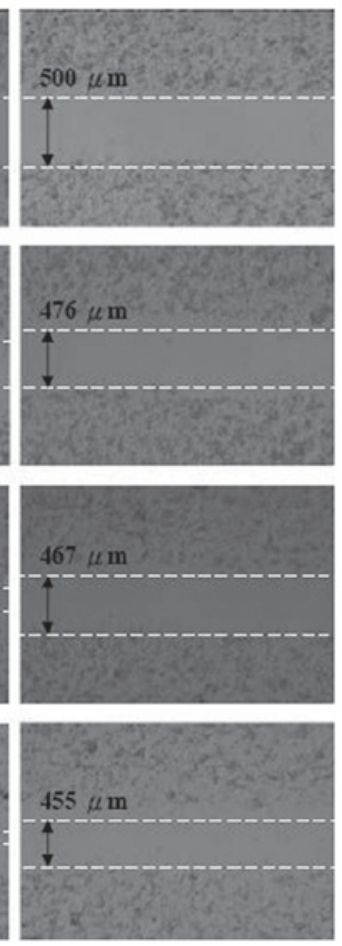

Figure 2. CEEF inhibits the migration of DU145 cells. The migration of DU145 cells was measured using the wound healing assay. Cells in a 6-well plate were treated with 0,50 and $75 \mu \mathrm{g} / \mathrm{ml}$ of CEEF for $0,6,12$ and $24 \mathrm{~h}$. Cells in the plate were examined and imaged using a contrast-phase microscope as described in Materials and methods. CEEF, crude extract of Euphorbia formosana. 
A coatrol
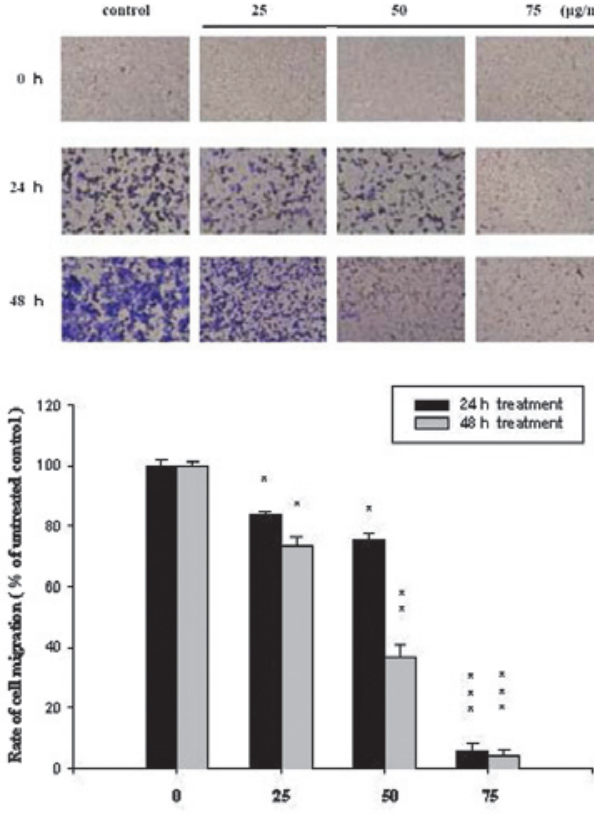

Concentration of CEEF ( $\mathrm{g} / \mathrm{ml}$ )
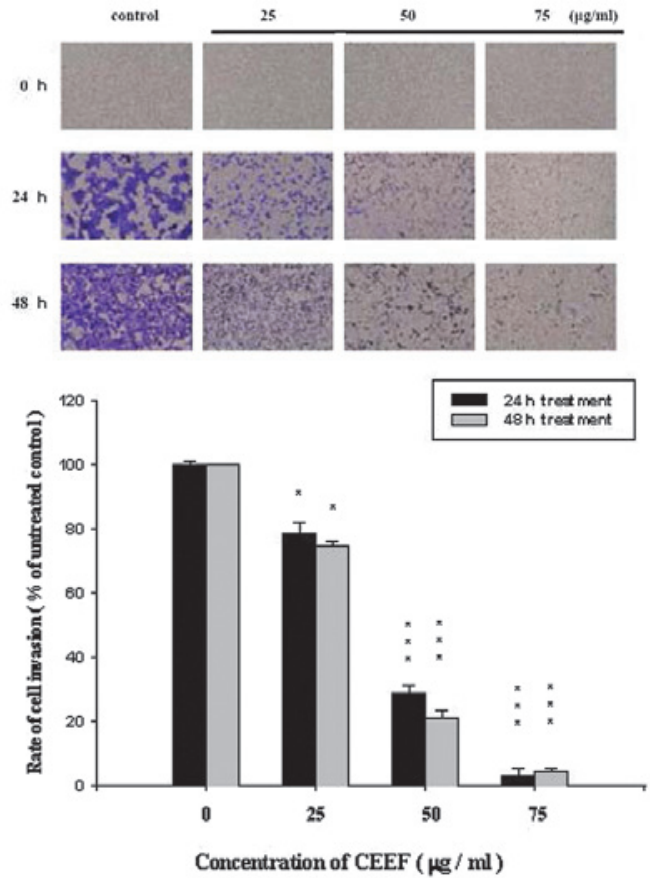

Figure 3. CEEF suppresses the migration and invasion of DU145 cells in vitro. Cells that penetrated through (A) without the Matrigel (migration) or (B) with the Matrigel (invasion) to the lower surface of the filter were stained with crystal violet and were imaged under a light microscope at $\mathrm{x} 200$. Quantification of cells in the lower chambers was performed by counting cells at x200. Columns repeat the mean from three independent experiments. CEEF, crude extract of Euphorbia formosana.

A

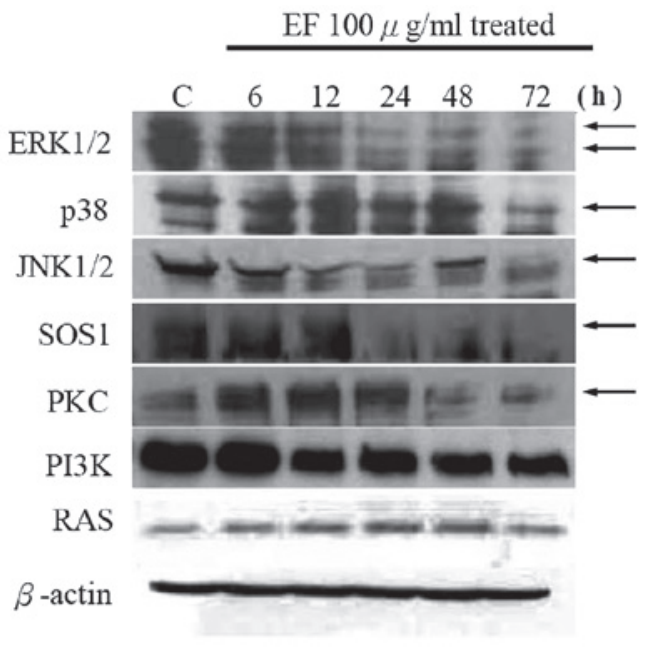

B

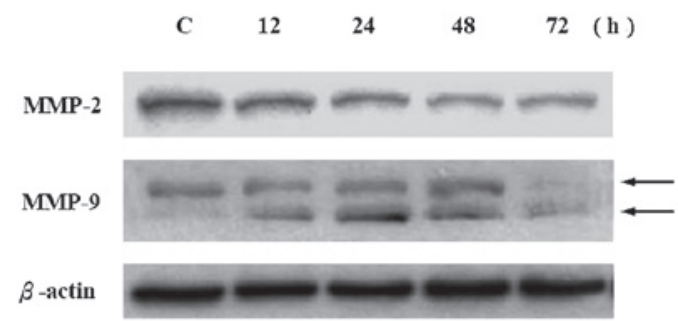

Figure 4. CEEF affects the levels of proteins associated with the migration and invasion of DU145 cells. Cells were treated with CEEF at 0 and $100 \mu \mathrm{g} /$ $\mathrm{ml}$ for $0,6,12,24,48$ and $72 \mathrm{~h}$ and then collected. The total protein was obtained as described in Materials and methods. The levels of (A) ERK, JNK, p38, SOS1, PKC and PI3K, and (B) MMP-2/9 expression were estimated by Western blotting as described in Materials and methods. CEEF, crude extract of Euphorbia formosana; MMP, matrix metalloproteinases.

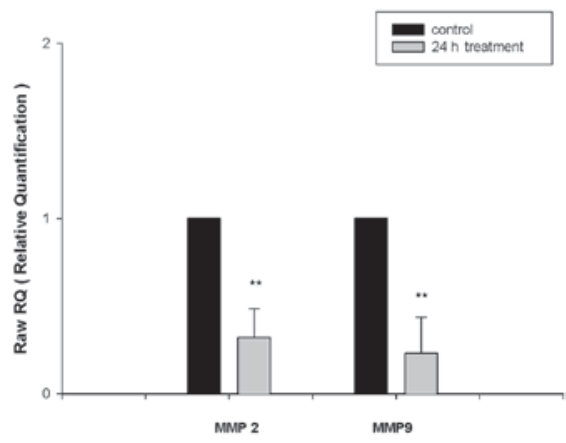

Figure 5. CEEF inhibits the mRNA expression levels of MMP-2/9 in DU145 cells. Cells $\left(1 \times 10^{6}\right.$ cells $\left./ \mathrm{ml}\right)$ in a 12 -well plate were treated with $100 \mu \mathrm{g} / \mathrm{ml}$ CEEF for $24 \mathrm{~h}$. Cells were washed with PBS and collected. Total RNA was obtained for real-time PCR as described in Materials and methods. Significantly different from the control- and CEEF-treated groups at ${ }^{* *} \mathrm{P}<0.01$. CEEF, crude extract of Euphorbia formosana; MMP, matrix metalloproteinases.

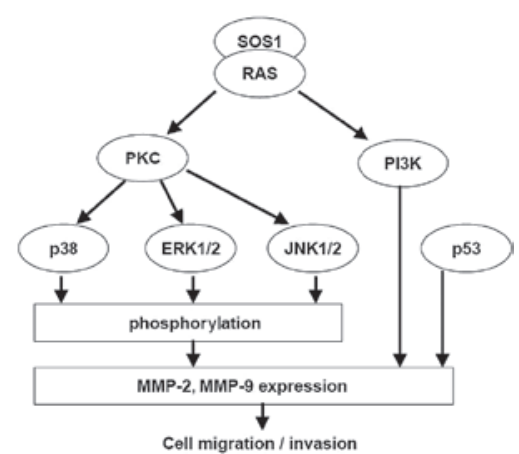

Figure 6. Potential signaling pathways involved in the inhibition of cell invasion and migration of DU145 human prostate cancer cells by CEEF. CEEF, crude extract of Euphorbia formosana; MMP, matrix metalloproteinases. 
and apoptosis in DU145 prostate cancer cells (data not shown) In the present study, we investigated the mechanisms of the anti-migratory and anti-invasive effects of CEEF in DU145 prostate cancer cells. At the CEEF concentrations used, no effects on the growth rate of DU145 cells were observed (Fig. 1A). However, anti-migratory and anti-invasive effects were observed at CEEF concentrations which did not significantly inhibit cell growth (between 12.5 and $200 \mu \mathrm{g} / \mathrm{ml}$ ). We conclude that the effects of CEEF on migration and invasion were not due to cytotoxicity.

It is well known that the uncontrolled degradation of the extracellular matrix and basement is associated with tumor cell invasion and migration, and that MMPs are important in cancer cell migration and invasion $(23,27)$. In the present study, the secretion levels of MMP-2/9 (Figs. 4B and 5) were downregulated by CEEF treatment and these effects were concentration- and time-dependent. Western blotting also demonstrated that MMP-2/9 protein levels were reduced by CEEF (Fig. 5B). Overexpression of MMP-2/9 has been observed in different human cancer types and those proteins are associated with a high potential for metastasis $(31,39,40)$. We hypothesize that a significant downregulation of MMP-2/9 secretion levels in CEEF-treated DU145 cells may be involved in reducing protein levels of MMP-2/9. In addition, CEEF reduced the protein levels of ERK1/2, JNK1/2, p38, SOS1 and PI3K (Fig. 4A). MAPK pathways involving ERK, JNK, p38 and ERK signaling have been reported to upregulate the expression of MMPs $(31,41)$.

A model of the potential action of CEEF on the migration and invasion of DU145 cells is shown in Fig. 6. CEEF may inhibit the migration and invasion of DU145 cells via the MAPK (ERK1/2, JNK1/2 and p38) signaling pathway resulting in the subsequent downregulation of MMP-2/9 expression levels. Future studies are needed to address whether CEEF inhibits tumor migration and invasion in animal models.

\section{Acknowledgements}

This study was supported in part by research grants CMU99-COL-06-1 and CMU99-COL-06-2 from China Medical University.

\section{References}

1. Baumunk D, Blana A, Ganzer R, Henkel T, Köllermann J, Roosen A, Machtens S, Salomon G, Sentker L, Witzsch U, Köhrmann KU and Schostak M: Focal prostate cancer therapy: Capabilities, limitations and prospects. Urologe A: Oct 18, 2012 (Epub ahead of print) (In German).

2. Obertova Z, Brown C, Holmes M and Lawrenson R: Prostate cancer incidence and mortality in rural men - a systematic review of the literature. Rural Remote Health 12: 2039, 2012.

3. van der Meer S, Löwik SA, Hirdes WH, Nijman RM, Van der Meer K, Hoekstra-Weebers JE and Blanker MH: Prostate specific antigen testing policy worldwide varies greatly and seems not to be in accordance with guidelines: a systematic review. BMC Fam Pract 13: 100, 2012.

4. Cheng L, Montironi R, Bostwick DG, Lopez-Beltran A and Berney DM: Staging of prostate cancer. Histopathology 60: 87-117, 2012

5. Provenzano M: New biomarkers in prostate cancer. Praxis (Bern 1994) 101: 115-121, 2012 (In German).

6. Ou YC, Chen JT, Cheng CL, Ho HC and Yang CR: Radical prostatectomy for prostate cancer patients with prostate-specific antigen >20 ng/ml. Jpn J Clin Oncol 33: 574-579, 2003.
7. Mener DJ: Prostate specific antigen reduction following statin therapy: Mechanism of action and review of the literature. IUBMB Life 62: 584-590, 2010.

8. Roy M, Kung HJ and Ghosh PM: Statins and prostate cancer: role of cholesterol inhibition vs. prevention of small GTP-binding proteins. Am J Cancer Res 1: 542-561, 2011.

9. Zhang Y, Ma B and Fan Q: Mechanisms of breast cancer bone metastasis. Cancer Lett 292: 1-7, 2010.

10. Karakiewicz PI and Hutterer GC: Predictive models and prostate cancer. Nat Clin Pract Urol 5: 82-92, 2008.

11. Karlou M, Tzelepi V and Efstathiou E: Therapeutic targeting of the prostate cancer microenvironment. Nat Rev Urol 7: 494-509, 2010.

12. Khamis ZI, Iczkowski KA and Sang QX: Metastasis suppressors in human benign prostate, intraepithelial neoplasia, and invasive cancer: their prospects as therapeutic agents. Med Res Rev 32: 1026-1077, 2012.

13. Minato N, Takada T, Koga M and Sugao H: Prostate cancer with disseminated carcinomatosis of bone marrow initially presenting with disseminated intravascular coagulation syndrome: a case report. Hinyokika Kiyo 58: 249-253, 2012 (In Japanese).

14. Payne H, Khan A, Chowdhury S and Davda R: Hormone therapy for radiorecurrent prostate cancer. World J Urol: Sep 21, 2012 (Epub ahead of print)

15. Smith BN and Odero-Marah VA: The role of Snail in prostate cancer. Cell Adh Migr 6: 433-441, 2012.

16. Hour MJ, Tsai SC, Wu HC, Lin MW, Chung JG, Wu JB, Chiang JH, Tsuzuki M and Yang JS: Antitumor effects of the novel quinazolinone MJ-33: Inhibition of metastasis through the MAPK, AKT, $\mathrm{NF}-\kappa \mathrm{B}$ and AP-1 signaling pathways in DU145 human prostate cancer cells. Int J Oncol: Jul 18, 2012 (Epub ahead of print).

17. Lee KH, Choi EY, Hyun MS and Kim JR: Involvement of MAPK pathway in hypoxia-induced up-regulation of urokinase plasminogen activator receptor in a human prostatic cancer cell line, PC3MLN4. Exp Mol Med 36: 57-64, 2004.

18. Mulholland DJ, Kobayashi N, Ruscetti M, Zhi A, Tran LM, Huang J, Gleave M and Wu H: Pten loss and RAS/MAPK activation cooperate to promote EMT and metastasis initiated from prostate cancer stem/progenitor cells. Cancer Res 72: 1878-1889, 2012.

19. Guo LW, Gao L, Rothschild J, Su B and Gelman IH: Control of protein kinase $\mathrm{C}$ activity, phorbol ester-induced cytoskeletal remodeling, and cell survival signals by the scaffolding protein SSeCKS/GRAVIN/AKAP12. J Biol Chem 286: 38356-38366, 2011.

20. Marques RB, Dits NF, Erkens-Schulze S, van Ijcken WF, van Weerden WM and Jenster G: Modulation of androgen receptor signaling in hormonal therapy-resistant prostate cancer cell lines. PLoS One 6: e23144, 2011.

21. Kanoh Y, Ohtani H, Egawa S, Baba S and Akahoshi T: Changes of proteases and proteinase inhibitors in androgen-dependent advanced prostate cancer patients with alpha2-macroglobulin deficiency. Clin Lab 58: 217-225, 2012.

22. Ramsay AK, McCracken SR, Soofi M, Fleming J, Yu AX, Ahmad I, Morland R, Machesky L, Nixon C, Edwards DR, Nuttall RK, Seywright M, Marquez R, Keller E and Leung HY: ERK5 signalling in prostate cancer promotes an invasive phenotype. Br J Cancer 104: 664-672, 2011.

23. Xiao LJ, Lin P, Lin F, Liu X, Qin W, Zou HF, Guo L, Liu W, Wang SJ and Yu XG: ADAM17 targets MMP-2 and MMP-9 via EGFR-MEK-ERK pathway activation to promote prostate cancer cell invasion. Int J Oncol 40: 1714-1724, 2012

24. Low JA, Johnson MD, Bone EA and Dickson RB: The matrix metalloproteinase inhibitor batimastat (BB-94) retards human breast cancer solid tumor growth but not ascites formation in nude mice. Clin Cancer Res 2: 1207-1214, 1996.

25. Wojtowicz-Praga SM, Dickson RB and Hawkins MJ: Matrix metalloproteinase inhibitors. Invest New Drugs 15: 61-75, 1997.

26. Shinoda K, Shibuya M, Hibino S, Ono Y, Matsuda K, Takemura A,Zou D, Kokubo Y, Takechi A and Kudoh S: A novel matrix metalloproteinase inhibitor, FYK-1388 suppresses tumor growth, metastasis and angiogenesis by human fibrosarcoma cell line. Int J Oncol 22: 281-288, 2003.

27. Yu CC, Hsieh CR, Hsiao G, Chen PY, Chang ML, Yin HW, Lee TH and Lee CK: Regulated expressions of MMP-2, -9 by diterpenoids from Euphorbia formosana Hayata. Molecules 17: 2082-2090, 2012

28. Lee MH, Yang HI, Lu SN, Jen CL, You SL, Wang LY, Wang CH, Chen WJ and Chen CJ: Chronic hepatitis C virus infection increases mortality from hepatic and extrahepatic diseases: a communitybased long-term prospective study; R.E.V.E.A.L.-HCV Study Group: J Infect Dis 206: 469-477, 2012. 
29. Lu CC, Yang JS, Chiang JH, Hour MJ, Amagaya S, Lu KW, Lin JP, Tang NY, Lee TH and Chung JG: Inhibition of invasion and migration by newly synthesized quinazolinone MJ-29 in human oral cancer CAL 27 cells through suppression of MMP-2/9 expression and combined down-regulation of MAPK and AKT signaling. Anticancer Res 32: 2895-2903, 2012.

30. Chen YY, Chiang SY, Lin JG, Ma YS, Liao CL, Weng SW, Lai TY and Chung JG: Emodin, aloe-emodin and rhein inhibit migration and invasion in human tongue cancer SCC-4 cells through the inhibition of gene expression of matrix metalloproteinase-9. Int J Oncol 36: 1113-1120, 2010.

31. Ma CY, Ji WT, Chueh FS, Yang JS, Chen PY, Yu CC and Chung JG: Butein inhibits the migration and invasion of SK-HEP-1 human hepatocarcinoma cells through suppressing the ERK, JNK, p38, and uPA signaling multiple pathways. J Agric Food Chem 59: 9032-9038, 2011.

32. Hu WG, Li JW, Feng B, Beveridge M, Yue F, Lu AG, Ma JJ Wang ML, Guo Y, Jin XL and Zheng MH: Vascular endothelial growth factors $\mathrm{C}$ and $\mathrm{D}$ represent novel prognostic markers in colorectal carcinoma using quantitative image analysis. Eur Surg Res 39: 229-238, 2007.

33. Ma D, Gerard RD, Li XY, Alizadeh H and Niederkorn JY: Inhibition of metastasis of intraocular melanomas by adenovirusmediated gene transfer of plasminogen activator inhibitor type 1 (PAI-1) in an athymic mouse model. Blood 90: 2738-2746, 1997.

34. Maarouf A, Adham M, Scoazec JY and Partensky C: Mixed hepato/cholangiocarcinoma with paraneoplastic hypercalcemia. J Hepatobiliary Pancreat Surg 15: 224-227, 2008.

35. Yang D, Gu T, Wang T, Tang Q and Ma C: Effects of osthole on migration and invasion in breast cancer cells. Biosci Biotechnol Biochem 74: 1430-1434, 2010.
36. Lin SS, Lai KC, Hsu SC, Yang JS, Kuo CL, Lin JP, Ma YS, Wu CC and Chung JG: Curcumin inhibits the migration and invasion of human A549 lung cancer cells through the inhibition of matrix metalloproteinase-2 and -9 and Vascular Endothelial Growth Factor (VEGF). Cancer Lett 285: 127-133, 2009.

37. Liu JW, Cai MX, Xin Y, Wu QS, Ma J, Yang P, Xie HY and Huang DS: Parthenolide induces proliferation inhibition and apoptosis of pancreatic cancer cells in vitro. J Exp Clin Cancer Res 29: 108, 2010.

38. Qin JM, Yin PH, Li Q, Sa ZQ, Sheng X, Yang L, Huang T, Zhang M, Gao KP, Chen QH, Ma JW and Shen HB: Anti-tumor effects of brucine immuno-nanoparticles on hepatocellular carcinoma. Int J Nanomedicine 7: 369-379, 2012.

39. Weigel MT, Kramer J, Schem C, Wenners A, Alkatout I, Jonat W, Maass $\mathrm{N}$ and Mundhenke C: Differential expression of MMP-2, MMP-9 and PCNA in endometriosis and endometrial carcinoma. Eur J Obstet Gynecol Reprod Biol 160: 74-78, 2012.

40. Zheng W, Zhang Y, Ma D, Shi Y, Liu C and Wang P: (+/-)Equol inhibits invasion in prostate cancer DU145 cells possibly via down-regulation of matrix metalloproteinase-9, matrix metalloproteinase-2 and urokinase-type plasminogen activator by antioxidant activity. J Clin Biochem Nutr 51: 61-67, 2012.

41. Ho YT, Yang JS, Li TC, Lin JJ, Lin JG, Lai KC, Ma CY, Wood WG and Chung JG: Berberine suppresses in vitro migration and invasion of human SCC-4 tongue squamous cancer cells through the inhibitions of FAK, IKK, NF-kappaB, u-PA and MMP-2 and -9. Cancer Lett 279: 155-162, 2009. 